\title{
In Defense of Clichés: Life Writing as Iteration and Interrogation
}

\author{
Carl Leggo
}

\begin{abstract}
For over 30 years I have been committed to theorizing, interrogating, and practicing life writing as an academic, pedagogical, and curricular discipline. In my life writing I often write what one reviewer called "clichés of the heart." I wonder what is wrong with clichés. Why are so many people so ready to criticize others for clichés? In an effort to address these kinds of concerns and questions, I offer 13 poetic, narrative, and citational ruminations in defense of clichés. I am eager to understand how clichés are connected to writing about life and learning how to live informed by writing.
\end{abstract}

We don't know that we can fight against ourselves, against the accumulation of mental, emotional, and biographical clichés. The general trend in writing is a huge concatenation of clichés. (Cixous, 1993, p. 119)

Critical acceptance of my inconclusion necessarily immerses me in permanent search. What makes me hopeful is not so much the certainty of the find, but my movement in search. (Freire, 1993, p. 106)

When my third book of poems, [Anonymized,] was published in 2006, one reviewer wrote in a local newspaper that I wrote "clichés of the heart." I suppose I should recall the cliché that "any review is better than no review." (I certainly know what it feels like to read no reviews!) Nevertheless, I continue to be both enthused and confused about the role of clichés as a tangled locus of critical and creative focus. As a poet and education scholar, I write about lived and living experiences. I engage with life writing which can be composed in a diverse range of discursive practices including biography, autobiography, letters, journals, diaries, stories, poetry, anecdotes, photography, Facebook, blogs, Tweets, and Instagram. I am 64 years old, and I have been engaging with life writing in reflexive and self-conscious ways since I was at least an adolescent, and for over 30 years I have been committed to theorizing, interrogating, and practicing life writing as an academic, pedagogical, and curricular discipline. In my life writing I often write "clichés of the heart." I wonder if I can avoid clichés. I also wonder what is wrong with clichés. Why are so many people so ready to criticize others for clichés? In an effort to address these concerns and questions, I offer 13 poetic, narrative, and citational ruminations in defense of clichés. I am especially eager to understand how clichés are connected to writing about life and learning how to live informed by writing.

Cliché

as luck would have it

I am a cliché

LEARNing Landscapes | Spring 2018, Vol. 11 No. 2 | 241 
trite threadbare twice-told

tired but happy, tried but true

a banal bromidic bathetic

specimen of humanity

well-worn warmed-over worn-out

doomed to disappointment

shopworn stale stock

along these lines

I am a cliché

prosaic platitudinous

working like a Trojan

jejune vapid shallow

no bolt from the blue

common flat dull

at the parting of the ways

over-used used-up

all too soon

I am a cliché

hackneyed stereotypical

with method in my madness

rubber stamped ready-made

safe and sound, sadder but wiser

derivative corny old hat

I set the wheels going

242 | LEARNing Landscapes | Spring 2018, Vol. 11 No. 2 
lifeless drained exhausted

still I was not always a cliché

once upon a time I was a word

repeated repeat repeated

repeat repeated repeat

once worth repetition

repetition rendered me worthless

the sprite turned trite

last as well as least

unable to keep up with the wor $(\mathrm{I}) \mathrm{d}$

as I grow older

always scribbled

I am more and more a cliché

my story more and more familiar

even before I have lived it

while less and less I write

my story written by others

too funny for words at least

a cliché in time saves nine

In the final grades of high school, I used the textbook Mastering Effective English. I still recall working through the section entitled "Avoid the Cliché," which sounds like the title of a Saturday matinee with monsters. The authors J. C. Tressler and C. E. Lewis (1961) explain that, "a cliché is a trite or hackneyed phrase that has lost vitality through over-use" (p. 30). They recognize that "the original was worth repetition or duplication," but the text that was originally precise has become "commonplace and worn out" (p. 30). They recommend that expressions like the following "have no place in writing that is sincere and natural" (p. 3): "all too soon," "bolt from a clear sky," "dull, sickening thud," "tired but happy," 
"safe and sound," "sadder but wiser," "too funny for words," "doomed to disappointment," and "where ignorance is bliss" (p. 31). As a 15-year-old writer, I was keen to compose "sincere and natural" writing. I did not know what that meant, but I was a good kid in school, and I was eager to learn from the textbooks and the teachers (who often seemed synonymous). So, I attended to Tressler and Lewis' "Practice 31. Eliminating Clichés" with a passionate conviction. When Tressler and Lewis invited me to "re-write the following sentences, substituting fresh and original expressions for what is trite," (p. 31), I labored over the 10 practice sentences with a convert's penchant for transformation (is that a cliché by the way?). I read the sentence: "Tired but happy after our hike in God's great out-of-doors, we wended our way home" (p. 31). At fifteen, I liked the sentence. I liked the sound of "tired but happy," which accurately expressed the way I often felt after a day of hiking and trout fishing in secret ponds only my father seemed to know about. I have always been sensitively aware of the presence of the spiritual and divine in nature. And I loved the word "wended" with its echoes of winded and wandered and wondered. I cannot recall how I rewrote the sentence in order to replace the trite with the fresh, but I probably wrote more clichés. When I was young I didn't know enough to avoid clichés. Now that I am old I still don't! Instead of avoiding clichés, as in Mastering Effective English, I now seek ways to deconstruct, question, and reinvent possibilities for acknowledging connections to clichés that still allow for newness as language is practiced with imagination and creativity.

How did the word cliché become a cliché-misused, overused, confused, and abused? In "The typographic imagination," Priya Joshi (2015) explains the invention of the original cliché:

Around 1800, a French printer developed a new technology to speed up the reprinting of popular titles. Rather than having to reset type each time a work needed to be reprinted, Firmin Didot found a way to cast type from the original plates of a work. The new technology, called stereotype (or cliché), was hailed for its accuracy, since the stereotype plate did not introduce errors into the reprinting process. (p. 521)

Though Didot's technology was initially popular because it allowed for economical and error-free reprinting of new editions, especially of popular novels, Joshi notes that by the middle of the 18th century, "the word 'stereotype' emerged to connote monotony, then conformity" (p. 521). Perhaps the word cliché has been moulded in the cauldron of binary oppositions and facile categorizations that seek the commonplace instead of the place of complexity. Perhaps the cliché is the boring cousin of originality. While I admire the ceramic bowl handmade by a potter who lives in my neighbourhood, I am also still happy to use Tupperware plastic bowls for numerous household tasks. Both bowls have value. In a similar way, even though I have heard many times that no two snowflakes are the same, most snowflakes impress me as quite similar. When snow falls at the beginning of winter, I am moved by an abiding sense of mystery and beauty — not because no two flakes are the same, but by the immensity of the snow, and by how the snow erases the world, renders invisible the world that has grown more and more familiar since spring. Now the familiar world is erased by snow that might be constituted of diverse shapes beyond counting, but still looks like the snow I grew up with in Newfoundland and have known in other provinces, too. The snow is a cliché. I am not sure how it can be anything else. 
In Defense of Clichés: Life Writing as Iteration and Interrogation

According to Richard E. Miller (2005), we now inhabit the age of the memoir, and, therefore, "we find ourselves surrounded by those who write to distinguish themselves from the crowd by capturing the deep particularity and pathos of their own past experiences" (p. 20). So, from Miller's perspective, more and more people are seeking to avoid the charge of cliché by sharing their specific, original, and unique stories. With smartphones in our pockets, we can all tell our stories, all the time, anywhere. Miller wonders if we can compose "writing that moves out from the mundane, personal tragedies that mark any individual life into the history, the culture, and the lives of the institutions that surround us all" (p. 25). In other words, can we write stories that move from the cliché of iterative personal experience into the elaborate, intricate webs of social, historical, cultural, ideological, institutional experiences that extend far beyond iteration into inimitable possibilities? Each of us knows our lived and living experiences in our own body, imagination, memory, mind, and heart. From the perspective of my l-consciousness, from my self-centered location as the one who speaks the pronoun $I$ and who is spoken into being by the discursive signification of the pronoun I, I can readily fail to attend to other pronouns, especially you and we. My story is similar to the stories of many others. Like many others, I was born. I anticipate I will die. In between, I grow older, remember childhood, adolescence, and decades of adulthood, and linger daily with a keen sense of surprise I am 64 years old! This is not a unique story. I am a cliché, but this selfknowledge is the awareness that can infuse me with a desire to know others, too. I am part of an interconnected network of creatures, sentient and nonsentient, who linger or who have lingered in the creation. Miller calls for "writing as a place where the personal and the academic, the private and the public, the individual and the institutional, are always inextricably interwoven" (p. 31). Instead of accusing another of being a cliché, perhaps we need to learn how to attend to the stories of others, so we can know their stories and our stories, too, in relationships that are inexhaustible.

Edwina Attlee (2015) notes that writers know "clichés are bad," but she asks, "Can attentiveness to them ever be more than an aesthetic activity? Can it be political?" (p. 1). Because the cliché is connected with the evolution of the printing press and the provision of relatively inexpensive books for eager consumers, Attlee observes that, "at the heart of the cliché lurks a rather uneasy confabulation of the democratic and the debasement of the singular by the plural" (pp. 1-2). Therefore, Attlee notes that, "a poetics of the cliché asks at what point does the stereotype solidify? When does an original become old hat?" (p. 2). She also wonders if the process is reversible (p. 2) because "to recognise a cliché is to engage critically with the text as part of a history of texts" (p. 2). The cliché reminds us about the limits of language. The cliché reminds us that there is always much more to be said or gestured or imagined. The cliché reminds us to pay attention to the unsayable, the incommunicable, the inexpressible, the ineffable, the unspeakable. The cliché reminds us to stretch language, to interrogate language. Perhaps the cliché can be repurposed, re-inspirited, and revitalized. As an old man, almost everything I do feels or seems like a cliché. The problem is not really the cliché which serves a valuable purpose in printing and communicating. Unfortunately, the cliché has been used by many people as a shortcut in order to avoid needing to communicate much at all. Working with words is hard work. Finding the language to share 
your story is hard work. Life writing is hard heart work. Clichés provide an easy way in and out. Quick and simple.

I once wrote a poem about my Uncle Jim who built boats and taught me some lasting lessons about writing poetry.

I'm Alone

two ways to build a boat, says Uncle Jim,

pounding each nail with three swings

so exact and rhythmic you'd think

he was a rechargeable Black and Decker hammer;

you can start from scratch and dream the plans

in the air and on paper or you can begin

with an old boat and replace each plank and rib,

piece by piece, until the old boat is firewood

and the new boat is the old boat's image;

the second way is slower, but I like a boat

with family connections; so Uncle Jim built

a plastic shack over the beached skiff,

years earlier named the I'm Alone

after a rum-running schooner that plied

the eastern seaboard, and searched the autumn

woods for timbers and laid the new keel

in November and the ribs in December

with Bud and Skipper and Fox dropping by

to offer advice and clint nails,

but the boat-building stopped in January 
when Uncle Jim drove Fox up to Corner Brook

to the hospital, Fox smiling through his pain

that he was okay, but he wasn't okay

with most of his stomach cancer-eaten,

and all through the winter Uncle Jim

couldn't work on the I'm Alone

while Fox died daily and died finally in May,

and in the summer that spring

didn't make it to the top of the hills

Uncle Jim began building the I'm Alone again,

wishing a person could be replaced,

plank by plank, rib by rib, as easily as a boat

I have no doubt that my poem "I'm Alone" is a cliché. Reviewers might trash the poem for a sentimental effort to narrate the experience of loss and grief. Death is commonplace. That is a big problem with death. On the one hand, people die every day. I pay little attention to the death of most people. Then, my brother dies six weeks after a diagnosis of cancer, and all I can think about is his dying, his absence, and the poignant ache of silence. I spent enough time with my Uncle Jim and my father and their circle of friends to understand the grief they all shared when Fox was first diagnosed with cancer and when he died. Death might be a cliché, but the death of Fox pressed hard on the hearts of his family and friends. The death of my brother presses hard on my heart. I am a cliché, and I live clichés, and my heart is "a huge concatenation of clichés" (Cixous, 1993, p. 119). Reviewers criticize my poetry because it fails to speak to them in original or inventive ways, but I cannot control the reception of my work. I write poetry in order to help myself understand the rhythms of each day's joys and challenges, especially as I experience and witness each day's stories. In other words, I do not write poetry in order to say something novel, something that has not been said, something that will please a reviewer. I think everything has already been said, and I am just seeking ways to say again what has already been said.

The poem "I'm Alone" is a testimony to family and friends who support one another in good times and tough times. Uncle Jim and my father and their friends enjoyed building boats together, and they learned together the craft of boat building. When they built the I'm Alone they deliberately chose to build a kind of replica of another boat. By replacing the parts of the old boat with new parts that resembled the old parts, they created a boat "with family connections." Building the I'm Alone was an act of love. 
As I continue my exploration of the role of clichés in writing, especially in writing about our lives, I will next follow my Uncle Jim's advice and build some writing around the ribs and planks of an earlier essay, "Blank page or scribbled page: Intertextuality and the fear of writing," which was published in 1994. When invited to write, many students moan that they do not know what to write about. They confess their fear of the blank page. I am always surprised because I do not see the blank page. Instead, I see a scribbled page, already extensively written by others. I am constantly asking if I have anything worth writing. Who would want to read my writing? Like Richard E. Miller (2005), I ask: "Why go on teaching when everything seems to be falling apart? Why read when the world is overrun with books? Why write when there's no hope of ever gaining an audience?" (p. x). In a long-privileged career as a professor, I have written many essays, poems, stories, and books, but does the world really need more words, especially from me? The question is likely inappropriate. In "the age of mass loquacity" (Amis, 2000, p. 6), many of us are hoping for citations on Google Scholar or likes on Facebook or retweets on Twitter. Perhaps we are seeking celebrity. Certainly many of us feel like we are competing with one another for a seat at the table. Perhaps we need to surrender the claim to our unique and idiosyncratic experiences, perspectives, and emotions in order to appreciate our commonplaces, and the opportunities for communication and community.

Writers often feel a sense of anxiety about how their writing will never gain an audience. In reflecting on Stephane Mallarme's anxiety about the influence of well-established writers, Barbara Johnson (1985) notes that, "impotence is...not a simple inability to write, but an inability to write differently. The agony experienced before the blank page arises out of the fact that the page is in fact never quite blank enough" (p. 269). This is my experience. I read widely. I have devoted much of my life to reading. Now that I am old and drawing near the end of my academic career, I sometimes think that I should simply stop writing, and devote more time to reading the writing of others. I am usually concerned that my writing is not sufficiently different. In other words, I am frequently concerned that my writing is clichéd! What I need to acknowledge is that all writing is intertextual. As Johnson explains, "intertextuality' designates the multitude of ways a text has of not being self-contained, of being traversed by otherness" (p. 264). Every text bears traces of numerous other texts including: allusions, citations, codes, conventions, images, phrases, references, themes, and tropes. I am intertextually connected to a network of writers, a mosaic of textual production. There are no blank pages; there are only scribbled pages. I recall John Barth's (1984) advice:

We should console ourselves that one of the earliest extant literary texts (an Egyptian papyrus of ca. 2000 B.C., cited by Walter Jackson Bate in his 1970 study The Burden of the Past and the English Poet) is a complaint by the scribe Khakheperresenb that he has arrived on the scene too late:

Would I had phrases that are not known, utterances that are strange, in new language that has not been used, free from repetition, not an utterance that has grown stale, which men of old have spoken. (p. 206) 
By citing Barth who cites Bate who cites Khakheperresenb, I enter into a chorus of iterative writing and citational practices that is already more than 4,000 years old. Like an expansive rhizome, my writing invites others to continue the intertextual connections by citing Author who cites Barth who cites Bate who cites Khakheperresenb who lamented long ago about the inescapable necessity of citing others. As the ancient Hebrew Teacher noted, "Of making many books there is no end" (Ecclesiastes 12:12). While I hear a tone of weariness in the Teacher's observation, I am still encouraged that "making many books" is a way of inviting communication in discourse communities as we learn to share our stories with one another. The page is never impossibly blank nor is it impassibly scribbled. There is always room for more writing, just as living stories continue to unfold, day by day, in all their delightfully clichéd familiarity.

More than three decades ago I read an interview with Ronald Sukenick (1983), and while his words initially impressed me and lingered a long time, I recently revisited the interview. I was less enamoured. Sukenick claims that

one of the main purposes of really good writing is to destroy other really good writing, to destroy all the old concepts and formulas that come out of the best of the past. You should destroy them lovingly and with great consciousness and awareness of them, but always with the end in mind of getting beyond them again. (p. 282)

As a young man I was likely attracted to Sukenick's call for destroying "old concepts and formulas." Now that I am an old man, I am less interested in destroying the old, especially because I now have a more informed understanding of the value of the past, of history and foundations. At the same time I first read Sukenick, I also read Jacques Derrida's (1981) notion of writing as grafting on a host text: "It is necessary to read and reread those in whose wake I write, the 'books' in whose margins and between whose lines I mark out and read a text simultaneously almost identical and entirely other" (p. 4). I especially like the notion of "a text simultaneously almost identical" but also "entirely other." Perhaps writing dwells in the space between the same and the other. Perhaps we are too enamoured with the notion of the other, the strange, the unfamiliar.

Jeanette Winterson (1995) thinks that "the calling of the artist, in any medium, is to make it new" (p. 12), but she does not mean that, "in new work the past is repudiated; quite the opposite, the past is reclaimed" (p. 12). For Winterson, the past "is re-stated and re-instated in its original vigour" (p. 12) which she understands "is not so much influence as it is connection" (p. 12). In my writing I am seeking intertextual connections with others and the stories of others. For Mikhail Bakhtin (1981) writing is "a living mix of varied and opposing voices...developing and renewing itself" (p. 49). Every writer is part of a community, a participant in a chorus of voices, seeking to perform that which is both new and not-new, acknowledging what has been said and what might be said. 
Thomas King (2003) once wrote that, "the truth about stories is that that's all we are" (p. 2). This comment has been cited so often that it now sounds like a cliché. At least to me who has read and heard it quoted many times. Of course, if you have never read Thomas King or heard a scholar citing King, the quotation would not likely strike you as a cliché at all. I like the comment very much, and I really don't care if some readers might regard it as a cliché. "The truth about stories is that that's all we are." This is the kind of thoughtful and eloquent comment about the importance of stories in our lives that I am always seeking to understand and promote. It is a poignant statement. In a similar way, Julia Kristeva (2001) reminds us that, "life is a story" (p. 6) And according to Christina Baldwin (2005), "story is the mother of us all" (p. 73).

Perhaps the big challenge of stories and clichés is that we can become trapped in a story that never changes. Regarding stories of his father's desertion, King (2003) writes: "stories can control our lives, for there is a part of me that has never been able to move past these stories, a part of me that will be chained to these stories as long as I live" (p. 9). We can be chained to stories that work like clichés. As King understands, "we do love our dichotomies" (p. 25), and "we trust easy oppositions. We are suspicious of complexities, distrustful of contradictions, fearful of enigmas" (p. 25). Story is the way we frequently understand our world, the way we live in the world in relationship to other people. We live in the world reflecting on our past experiences. We live in the world with dreams about the future. And in all of these ways, we are thinking and dreaming and creating narratively; we are thinking in stories; we are living (in) stories. But the stories are also living in us, composing us. Because "stories are wondrous things" and because "they are dangerous" (p. 9), King recommends that we "be careful with the stories" we tell and that we "watch out for the stories" we are told (p. 10).

According to Edwina Attlee (2015), "the cliché that is passively absorbed or used does not require any thought" (p. 5). Attlee is intrigued by poetry that constantly disturbs "fixity and consistency" by resisting "the trap of the cliché whilst calling attention to it" thereby displaying "an ambivalence towards communication" (p. 5). I once wrote a poem titled, "Alphabet Soup and an Invitation to Write (a) Perfect Poem(s)." The poem is a found poem that comprises quotations from Canadian women writers who all wrote about the act of writing. The poem begins with a quotation from Margaret Atwood (1983):

I've said the page is white, and it is: white as wedding dresses, rare whales, seagulls, angels, ice and death. Some say that like sunlight it contains all colours; others, that it's white because it's hot, it will burn out your optic nerves; that those who stare at the page too long go blind. (p. 44)

I end the poem with a quotation from Susan Zimmerman (1980):

Consider the selfishness of poets

their ruthless naming of lovers

the way they tell the truth 
(when it's painful)

or twist the truth

(when it's not, to make it so). (n.p.)

In between Atwood and Zimmerman, I included quotations from 24 other women Canadian writers whose names began with the other letters of the alphabet, B to $\mathrm{Y}$, including Elizabeth Brewster, Anne Campbell, Louise Duprés, Marion East, and Patricia Young (1986) who wrote:

I wrote because I had to,

to rid myself of the awful sadness:

that's the story people read.

If I had to do it all over,

I guess I'd say no

to that.

I'd rather have been happy

than a writer. (p. 15)

I devoted a great deal of time and energy to composing the poem, "Alphabet Soup and an Invitation to Write (a) Perfect Poem(s)." I likely thought it was a clever undertaking. I certainly remember spending many pleasant hours in the library as I searched for more women Canadian writers with surnames that began with all the letters of the alphabet and who wrote about writing. When I submitted the poem for publication in a literary journal, the editor responded: "Isn't this plagiarism?" I was a little shocked. I included all the appropriate references for each quotation. I certainly aimed to be respectful of the writing of others. The question regarding plagiarism reminded me how much many writers and scholars fear iteration, even when it is presented in a novel way.

In the delightful fiction, "Pierre Menard, Author of the Quixote," Jorge Luis Borges (1939/1981) provides a witty perspective on plagiarism. While he recognizes the significant accomplishment of Miguel de Cervantes' Don Quixote, Borges explains how Pierre Menard committed his life to writing "the Don Quixote" (p. 99): "he did not propose to copy it. His admirable ambition was to produce pages which would coincide-word for word and line for line-with those of Miguel de Cervantes" (p. 99). Borges then presents a few lines from Cervantes' writing, and a few lines from Menard's writing. The lines are exactly the same, but Borges explains carefully how Cervantes enumerates "a mere rhetorical eulogy of history" (p. 102), while Menard defines history as an investigation of 
"its origin" (p. 102). Not only do I admire Borges' wit, but I am also reminded that we are always composing, deposing, disposing, decomposing, exposing, imposing, opposing, reposing, supposing, and transposing stories, images, persona, language, in our efforts to know how we are grounded and growing, located in places_-but also always in process.

Jakob Norberg (2014) claims that, "the problem with the cliché is one of iteration" (p. 2). Certainly that is the reason that a cliché is generally rejected as overused or "overly familiar" (p. 3). Nevertheless, is there any way to avoid iteration? According to Norberg, "if a person says that which everyone else is already saying, it is...a failure of self-disclosure, for one learns nothing about the particularity and individuality of the speaker" (p. 6). Perhaps the challenge is not the "failure of self-disclosure," but the eagerness to belong to a community that holds both particularity and commonality, individuality and plurality. When almost every server in restaurants I frequent responds to my expression of thanks for their service with the odd phrase "no problem," I realize that the phrase has acquired a strange and sudden currency like countless popular fads, twitches, and aphorisms. Everybody wants to present the appearance, the persona of cool, but cool is not idiosyncrasy, eccentricity, peculiarity, or singularity. $\mathrm{Cool}$ is culturally defined and determined. $\mathrm{Cool}$ is a cliché. Norberg claims that people who use clichés do not express themselves because "there is no distinct self to express" (p. 6). Instead, they are either expressing society, or they are conduits for society to express itself through them (p. 6)

But Martin Amis (2000) claims that, "experience is the only thing we share equally" (p. 6). As a novelist, Amis thinks the trouble with living experience "is its amorphousness, its ridiculous fluidity" (p. 7). Life is "thinly plotted, largely themeless, sentimental and ineluctably trite" (p. 7). So, most people are not seeking to stand out from the crowd. Instead, they are seeking a sense of belonging. We often question the experiences of being human, but we ought to pay more attention to the longing for human belonging. I like Amis' conviction that writing is "not communication but a means of communion" (p. 268). Unlike Norberg's concern that relying on cliché is "a failure of courage" (p. 6) as well as "a type of communicative failure" (p. 7), I think that using a cliché is an expression of communion, a declaration of belonging. When Hells Angels or Hutterites dress in their traditional and readily recognizable costumes, and drive Harley Davidson's or horse-drawn buggies, they belong to a club or community. They are clichéd, but that is the identity of imitation and iteration that they seek.

I agree with Norberg that "in the cliché...the expression is circulating so widely that you can no longer make out the voice of any particular person" (pp. 7-8), but I still disagree with Norberg's expressed concern because I do not think we need "the voice of any particular person." Instead, we need social discourse that will guide us to understand that you queue up for the bus, or do not litter, or do not destroy your neighbor's property. We need social discourse that will guide us to acknowledge a respectful environment that honors diversity. We cannot nurture diversity by spelling out only the particularity of different people. We must acknowledge the connections and interconnections that hold the idiosyncratic in ideological pluralism. 
When Didot created the original cliché, the stereotype that allowed a printer to save time and money, that original cliché was not the frequently used text (phrase, line, metaphor) that we now call a cliché. In Didot's time the cliché was the clamp that held the type together. The original cliché was a device for holding a text. Perhaps communication requires a device that can hold the text in place. Perhaps at least some lived experiences need to be held in place. I maintain a tidy closet where ties, pants, shirts, jackets, and sweaters are all organized and arranged so I know where everything is. Early in the morning, I am usually glad that I can find what I want with minimal effort. The cliché serves a purpose.

But who determines that a text is a cliché? How often does a text need to circulate before it is determined to be a cliché? What is the contemporary penchant for novelty? Does anyone really expect the Apple iPhone $X$ to be significantly better than the Apple iPhone 8 Plus (and why wasn't it called the Apple iPhone 8.5 or even the Apple iPhone 9?). Meaghan Morris (2015) cites a personal communication with the cultural historian Earl Jackson who claims that a cliché "saves time for the producer of an utterance" because "the cliché allows the utterer to say something without thinking, without recomplicating the discourse" (p. 266). In life writing I lean on the device of the cliché in order to find my way to other kinds of utterances, other kinds of discourse. The cliché is a useful device. Perhaps our lives are the clichés, and we learn to utter our experiences and emotions in novel ways as we work hard with language in order to make our lives. In turn, perhaps the cliché invites the listener or reader or viewer (depending on the media used to compose, present, and perform our life writing) to use the device of the cliché in order to gain a sense of positionality that helps all of us to understand ourselves in relation to others. In other words, the cliché provides a place to stand as understanding is sought.

A cliché might be an

adage

banality

copy

drivel

everyday

familiar

gibberish

humdrum

iteration 
jargon

known

lingo

maxim

neologism

overused

platitude

quote

reproduction

stereotype

truism

used

vernacular

well-worn

Xerox

yesterday

zestless

But a cliché might be much more. We need to learn how to resist cliché by resisting the use of cliché in clichéd ways. Just consider the ubiquity of cliché. Hollywood is cliché. Celebrity is cliché. TV is cliché. Pornography is cliché. Popular fiction is cliché. Style is cliché. Fast food is cliché. So much of educational practice is cliché. Where does cliché end? I am a cliché. Of course! A cliché is a way of communicating in short-hand, but that does not mean that all communication must only be short-hand. We can learn to tell our stories in more diverse ways for more diverse purposes for more diverse audiences. In order to do so, we must attend to both iteration and interrogation, all infused with imagination. 


\section{References}

Amis, M. (2000). Experience. New York, NY: Hyperion.

Attlee, E. (2015). Click, click, click: Cliché in the poetry of Emily Berry, Heather Phillipson and Sam Riviere. Dandelion: Postgraduate Journal and Arts Research, 5(2), 1-13.

Atwood, M. (1983). Murder in the dark: Short fictions and prose poems. Toronto, ON: Coach House.

Bakhtin, M. (1981). In M. Holquist (Ed.), The dialogic imagination (M. Holquist and C. Emerson, Trans.). Austin, TX: University of Texas Press.

Baldwin, C. (2005). Storycatcher: Making sense of our lives through the power and practice of story. Novato, CA: New World Library.

Barth, J. (1984). The Friday book: Essays and other nonfiction. New York, NY: G. P. Putnam's Sons.

Borge, J.L. (1939/1981). Pierre Menard, author of the Quixote. In E. R. Monegal and A. Reid (Eds.), Borges: A reader (pp. 96-103). (A. Bonner, Trans.). New York, NY: E. P. Dutton.

Cixous, H. (1993). Three steps on the ladder of writing. (S. Cornell and S. Sellers, Trans.). New York, NY: Columbia University Press.

Derrida, J. (1981). Positions. (A. Bass, Trans.). Chicago, IL: University of Chicago Press.

Freire, P. (1993). Pedagogy of the city. (D. Macedo, Trans.). New York, NY: Continuum.

Johnson, B. (1985). Les fleurs du mal arme: Some reflections on intertextuality. In C. Hosek and P. Parker (Eds.), Lyric poetry: Beyond new criticism (pp. 264-280). Ithaca, NY: Cornell University Press.

Joshi, P. (2015). The typographic imagination. Contemporary Literature, 56(3), 521-526.

King, T. (2003). The truth about stories: A Native narrative. Toronto, ON: House of Anansi Press.

Kristeva, J. (2001). Hannah Arendt: Life is a narrative. (F. Collins, Trans.). Toronto, ON:

University of Toronto Press.

Miller, R. E. (2005). Writing at the end of the world. Pittsburgh, PA: University of Pittsburgh Press.

Morris, M. (2015). Encountering typologies. Interventions, 17(2), 258-268,

Norberg, J. (2014). The cliché as complaint and critique. FORUM: University of Edinburgh Postgraduate Journal of Culture and the Arts, 18, 1-11.

Sukenick, R. (1983). Interview. In T. LeClair and L. McCaffery (Eds.). Anything can happen: Interviews with contemporary American novelists (pp. 279-297). Urbana, IL: University of Illinois Press.

Tressler, J. C., \& Lewis, C. E. (1961). Mastering effective English (3rd ed.). Toronto, ON: Copp Clark Publishing.

Winterson, J. (1995). Art objects: Essays on ecstasy and effrontery. Toronto, ON: Alfred A. Knopf Canada.

Young, P. (1986). All I ever needed was a beautiful room. Quarry, 35(1), 15-19.

Zimmerman, S. (1980). Nothing is lost. Vancouver, BC: Caitlin. 


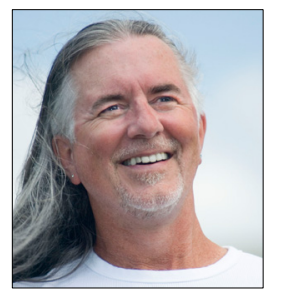

Carl Leggo is a poet and professor at the University of British Columbia, Vancouver, Canada. His research interests include: creativity, arts-based research, poetic inquiry, contemplative practices, and well-being. His books include: View From My Mother's House; Come-By-Chance; Lifewriting as Literary Métissage and an Ethos for Our Times (coauthored with Erika Hasebe-Ludt and Cynthia Chambers); Creative Expression, Creative Education (coedited with Robert Kelly); Sailing in a Concrete Boat: A Teacher's Journey; Arresting Hope: Prisons That Heal (coedited with Ruth Martin, Mo Korchinski, and Lynn Fels); Arts-based and Contemplative Practices in Research and Teaching: Honoring Presence (coedited with Susan Walsh and Barbara Bickel); Hearing Echoes (coauthored with Renee Norman); and Poetic inquiry: Enchantment of Place (coedited with Pauline Sameshima, Alexandra Fidyk, and Kedrick James). 